\title{
Phenotypic identification and numerical taxonomy of pigmented bacteria isolated from marine and freshwater aquatic at Yogyakarta, Indonesia
}

\author{
Fitri Indriana Susanti and Endah Retnaningrum* \\ Faculty of Biology, Universitas Gadjah Mada, Jl. Teknika Selatan Sekip Utara, Yogyakarta \\ 55281, Indonesia. \\ *e-mail: endahr@ugm.ac.id
}

\begin{abstract}
Numerical phenetic analysis was used to compare phenotypic data obtained from 6 isolates of pigmented bacteria strains taken from marine and river aquatic. Each strain was tested for 120 characters, analysed using the simple matching (SSM) and Jaccard (SJ) similarity indices with unweighted pair-group method with arithmetic mean (UPGMA) clustering method. All of the strains classified into two clusters, cluster A as marine pigmented bacteria and cluster B as river pigmented bacteria. Differences were observed between the dendrograms derived from the SSM and SJ. Presence of bacteriochlorophyll-a (Bchl-a), carotenoids, as well as other biochemical tests of three marine pigmented strains were in match with key characters of the genera Roseobacter, Roseateles and Erythrobacter. Three of river pigmented strains were identified as Xanthobacter, Flavobacterium and Pseudomonas. It was proved that the marine and river pigmented bacteria isolates showed a relative phenotypically distance. It was clearly seen that the phenetic approach was a necessary tool to delimitate and identify the pigmented bacteria from different habitats.
\end{abstract}

\section{Keywords}

bacteriochlorophyll-a, carotenoids, Jaccard similarity, pigment bacteria, simple matching

\section{Introduction}

Aerobic Anoxygenic Phototrophic (AAP) bacteria are group of aquatic microorganisms that possess photosynthetic pigment apparatus including bacteriochlorophyll-a (bchl-a) and carotenoids [1].

Citation: Susanti, F.I., Retnaningrum, E.: Phenotypic Identification and Numerical Taxonomy of Pigmented Bacteria Isolated from Marine and Freshwater Aquatic at Yogyakarta, Indonesia. In: I.W. Mustika, I. Kartini. (eds.): Proceeding of the 3rd International Conference on Science and Technology, Vol. 1, pp. 25-30. UGM Digital Press Physical Science and Engineering, Yogyakarta (2018).
Furthermore, they contribute significantly to the cycling of organic carbon in the upper aquatic environments [2]. Previous researchers have been estimated based on in situ measurements of their bchl-a to be responsible for as much as $5 \%$ to $10 \%$ of the energy generation in the upper layers of the tropical oceans [3,4].

Bacteriochlorophyll-a (bchl-a) and carotenoids content of AAP bacteria are induced of the light sources. These pigments are a group of chemically heterogeneous molecules that occur across several taxonomical groups. Due to the remarkable chemistry of aquatic organisms, many species exhibit a wide range of colors, many of which 
display several biological properties and constitute an evolutionary adaptation $[1,5]$.

These bacteria have been isolated from diverse environments, including marine water [6], river [3], wastewater treatment [7], and domestic wastewater treatment [8]. This group of AAP is also known as potential pollutans bioremediations such as heavy metal [9,10], azo dye [7], and miscellaneous pollutants $[11,12,13]$. Yogyakarta is one of Provinces in Indonesia which is geographically located in the middle of the plains region flanked by neighboring districts with high character of Mount Merapi slope in the north and coastal areas in the south. This region has special geographically character, consequently led to an abundance of natural resources and habitats. Sadranan intertidal zone of GunungKidul and Kalibiru River of Kulon Progo have specific condition, therefore it is important to compare phenotypic data obtained from 6 isolates of pigmented bacteria strains have been taken from marine and river aquatic in these environments.

\section{Materials and Methods}

\subsection{Strains and Culture Conditions}

Three of pigmented strains (Su-006, Su 007 and Su-010) were isolated from water in Kalibiru River, Kulon Progo, Yogyakarta, Indonesia. Whereas SdrW 001, SdrW-002 and SdrW-003 strains were isolated from sea water in Sadranan, intertidal zone, GunungKidul, Yogyakarta, Indonesia. Marine pigmented strains and river pigmented strains furthermore were grown routinely at $24{ }^{\circ} \mathrm{C}$ to $28{ }^{\circ} \mathrm{C}$ in PPS II and NB, respectively, on a rotating shaker at $200 \mathrm{rpm}$.

\subsection{Temperature, pH and Salinity Optimum, Biochemical Characteristics and Motility Assay}

Strains tested for the ability to grow at pH 5.5, 6.0, 7.5 and 8.0 were cultivated in liquid marine broth 2216 medium. The effect of 0.1 and $3 \% \mathrm{NaCl}$ on growth of the strains was tested in liquid marine broth 2216 medium. Results were recorded after 3 days of incubation. Growth temperatures were tested in PPS II and NB medium, respectively which were incubated in dim light for 1 week at 20, 25, 30 and $39{ }^{\circ} \mathrm{C}$. All of the above test strains were incubated on a rotating shaker at $200 \mathrm{rpm}$. The production of bacteriochlorophylla and carotenoid were assessed using Rhodopseudomonas palustris as a positive control. Methanolic extracts were measured with a Beckman DU-650 spectrophotometer (400 nm to $900 \mathrm{~nm}$ ). Tests were performed with strains grown at constant light at $10^{-15} \mu \mathrm{mol}$ photons $\mathrm{m}^{-2} \mathrm{~s}^{-1}$ or with strains grown in the dark. Catalase production, nitrate reduction, methylene blue reduction nitrite of the strains were determined by standard methods reported previously [14]. The ability to tetracycline resistance was investigated by using an agar surface plate method in which PPES II and NB were used. At least three independent assays were carried out for each strain.

\subsection{Statistical Methods}

The phenotypic data were coded for numerical analysis as binary characters. The binary characters were scored positive $(+)$ or negative (-). Data were analyzed using the NTSYS software package. Similarity matrices were calculated using the simple matching coefficient $\left(\mathrm{SS}_{\mathrm{M}}\right)$ and Jaccard coefficients $\left(\mathrm{S}_{\mathrm{J}}\right)$. Based on the $S_{S M}$ coefficient Unweighted Pair Group Method with Arithmetic Mean (UPGMA) clustering was achieved. 


\section{Results and Discussions}

\subsection{Identification of Strains}

All of the pigmented bacterial strains were gram negative, rod shapes and produce a small amount of acid from glucose, manitol, maltose, galactose, and sorbitol. Methanol was not utilized by any of the strains and none of the strains grew anaerobically in the light. The results of remaining test were displayed in Table 1. The optimum temperature and salinity of marine pigmented bacteria were between $20{ }^{\circ} \mathrm{C}$ to $30{ }^{\circ} \mathrm{C}$ and 0.1 $\%$ to $3 \% \mathrm{NaCl}$, respectively. On the contrary, the optimum salinity of river pigmented bacteria was of 0.1 $\%$ of $\mathrm{NaCl}$.

Table 1 Phenotypic characters of strains

\begin{tabular}{|c|c|c|c|c|c|c|}
\hline Characters & $\begin{array}{l}\text { Strains } \\
\text { SdrW-001 }\end{array}$ & SdrW-002 & SdrW-003 & Su-006 & Su-007 & Su-010 \\
\hline \multicolumn{7}{|l|}{ Morphology } \\
\hline Cell shape & rods & rods & Long rods & rods & Ovoid rods & rods \\
\hline Gram staining & negative & negative & negative & negative & negative & negative \\
\hline \multicolumn{7}{|c|}{ Cultural characteristics } \\
\hline Colony shape & circular & circular & irregular & circular & circular & amoeboid \\
\hline Colony color & pink & pink & orange & yellow & yellow & $\begin{array}{l}\text { Yellow- } \\
\text { brownish }\end{array}$ \\
\hline \multicolumn{7}{|l|}{$\begin{array}{l}\text { Growth } \\
\text { in/on/at: }\end{array}$} \\
\hline $0.1 \% \mathrm{NaCl}$ & + & + & + & + & + & + \\
\hline $3 \% \mathrm{NaCl}$ & + & + & + & - & - & - \\
\hline pH 5.5 & - & - & - & + & - & - \\
\hline pH 6, 7.5 & + & + & + & + & + & + \\
\hline pH 8 & - & - & + & + & + & + \\
\hline $20,25,30^{\circ} \mathrm{C}$ & + & + & + & + & + & + \\
\hline $39^{\circ} \mathrm{C}$ & - & - & - & - & - & + \\
\hline \multicolumn{7}{|c|}{ Biochemical properties } \\
\hline \multicolumn{7}{|c|}{$\begin{array}{l}\text { Production } \\
\text { acid from: } \\
\text { glucose }\end{array}$} \\
\hline manitol & + & + & + & + & + & + \\
\hline maltose & + & + & + & + & + & + \\
\hline galactose & + & + & + & + & + & + \\
\hline sorbitol & + & + & + & + & + & + \\
\hline methanol & - & - & - & - & - & - \\
\hline Catalase & + & + & + & + & + & + \\
\hline $\begin{array}{l}\text { Nitrate } \\
\text { reduction }\end{array}$ & - & - & - & - & - & - \\
\hline $\begin{array}{l}\text { Tetracycline } \\
\text { resistance }\end{array}$ & sensitive & resistance & sensitive & sensitive & sensitive & sensitive \\
\hline $\begin{array}{l}\text { Methylene blue } \\
\text { reduction }\end{array}$ & - & - & + & - & - & + \\
\hline Bchl-a & + & + & + & - & - & - \\
\hline Carotenoid & phytofluene & phytofluene & spirilloxanthin & phytofluene & lycopene & phytofluene \\
\hline $\begin{array}{l}\text { Absorption } \\
\text { spectra }\end{array}$ & $715 \mathrm{~nm}$ & $715 \mathrm{~nm}$ & $715 \mathrm{~nm}$ & $450-550 \mathrm{~nm}$ & $450-550 \mathrm{~nm}$ & $400-500$ \\
\hline $\begin{array}{l}\text { Identification } \\
\text { results }\end{array}$ & Roseobacter & Roseateles & Erythrobactre & Xanthobacter & Flavobacterium & Pseudomonas \\
\hline
\end{tabular}

All strains of marine pigmented bacteria (SdrW-001, SdrW-001 and SdrW-003) produced bacteriochlorophyll-a and carotenoid. These strains could grow under anaerobic condition and showed different color colony. Colony color of strain SdrW-001 and SdrW-003 were pink, whereas strain SdrW-002 was yellow. All of these strains produced carotenoid as phytofluene. The absorption spectra intracellular 
pigments of all strains were in the $450 \mathrm{~nm}$ to $550 \mathrm{~nm}$ region and there was no peak in the $700-800 \mathrm{~nm}$. Therefore, based on Bergeys Manual of Systematic, strain of SdrW-001, SdrW-001 and SdrW-003 were identified as Roseobacter, Roseateles and Erythrobacter, respectively [15].

River pigmented bacteria have a different characteristic with marine pigmented bacterial strain. These bacteria could not grow with high salinity and mineral salt. This condition was related with the environtment habitats of freshwater that contained only small ammount of mineral salts. All river pigmented bacteria strains were sensitive with tetracycline. Phenotypic characters between river pigmented bacteria almost the same, however the characters were different on colony color, carotenoid type and the absorption spectra of their intracellular pigment. Strain Su-006 had yellow colony, carotenoid type as phytofluene and the absorbtion spectra in the range of $450 \mathrm{~nm}$ to $550 \mathrm{~nm}$. Strain Su-007 had yellowbrownish colony, carotenoid type as lycopene and the absorbtion spectra in the range of $450 \mathrm{~nm}$ to $550 \mathrm{~nm}$ Strain Su-010 had yellow colony, carotenoid type as phytofluene and the absorbtion spectra in the range of 400-500 nm. Therefore, based on the key characters on Bergeys Mannual of Systematic Bacteriology with matching profile analyzed of strains Su-006, Su-007 and Su-010 were identified as Xanthobacter, Flavobacterium and Pseudomonas [15].

\subsection{Numerical Taxonomy}

Based on numeric phenetic analyzed, all of the strain were grouped into two clusters, cluster A was marine pigmented bacteria and cluster B was river pigmented bacteria. Although all of the strains were grouped into two clusters, but based on SSm and Sj analysis, all of the strains had similarity of $70 \%$ and $50 \%$, respectively (Fig. 1 and Fig. 2). Differences between two clusters of marine and river pigmented bacterial strains grouped by different characteristics in the marine and river bacteria such as growth temperature optimum, salinity, ability to reduce methylen blue and nitrate, and characteristic of cell absorbtion spectra that shown various photopigment and carotenoid.

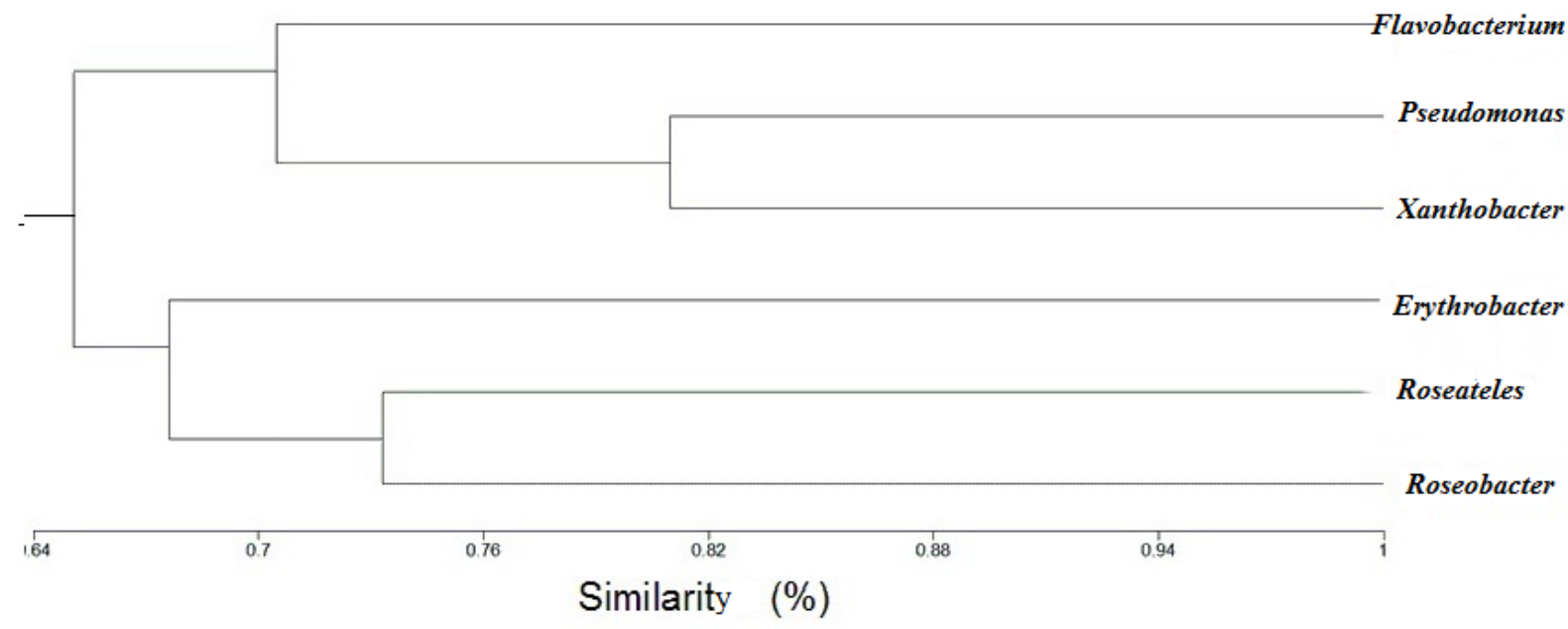

Fig. 1 Dendogram showing relationships between the strains based on SSM-UPGMA 


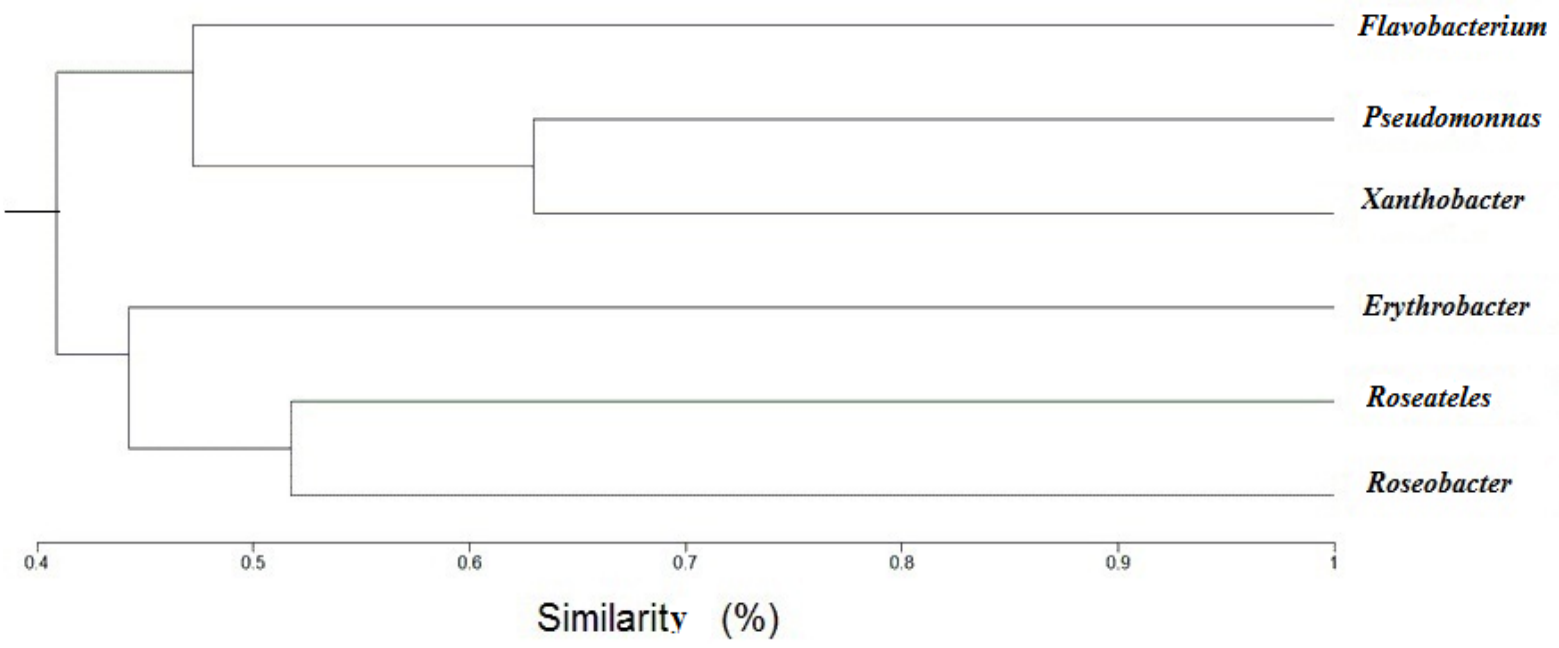

Fig. 2 Dendogram showing relationships between the strains based on SJ-UPGMA

\section{Conclusions}

Based on numeric phenetic analyzed, all of the strains were grouped into two clusters, cluster A was marine pigmented bacteria and cluster B was river pigmented bacteria. Classification and dendogram with $\mathrm{S}_{\mathrm{SM}}$ analyzed revealed that all of the strains grouped all into 3 species and then with Sj analyzed all of the strain fall into 4 species. It means the SJ analyzed more effective and valide than SSm analyzed. Based on Bergeys Mannual of Systematic Bacteriology and matching profile analyzed, six strains from sadranan intertidal zone and Kalibiru River identified as Rosebacter, Xanthobacter, Erythrobacter, Roseateles, Flavobacterium, and Pseudomonas.

Acknowledgments We thanked the technician in Falitma Laboratory, Biology Faculty, Universitas Gadjah Mada, Yogyakarta, Indonesia for their helpful authorization to use laboratory equipment.

\section{References}

1. Frigaard, N.U.: Biotechnology of Anoxygenic phototrophic bacteria. In: Hatti-Kaul, R., Mamo, G., Mattiasson, B. (eds.) Anaerobes in Biotechnology, pp. 139-154. Springer. Advances in Biochemical Engineering. Biotechnology. (2015).

2. Li, Q., Song, A., Peng, W., Jin, Z., Müller, W.E.G., Wang, X.: Contribution of aerobic anoxygenic phototrophic bacteria to total organic carbon pool in aquatic system of subtropical karst catchments, Southwest China: Evidence from hydrochemical and microbiological study. FEMS Microbiol. Ecol. 93, 1-8 (2017).

3. Hirose, S., Matsuura, K., Haruta, S.: Phylogenetically Diverse Aerobic Anoxygenic Phototrophic Bacteria Isolated from Epilithic Biofilms in Tama River, Japan. Microbes Environ. 31,299-306 (2016).

4. Šantić, D., Šestanović, S., Vrdoljak, A., Šolić, M., Kušpilić, G., Ninčević Gladan, Ž., Kobližek, M.: Distribution of aerobic anoxygenic phototrophs in the Eastern Adriatic Sea. Mar. Environ. Res. 130, 134-141 (2017). 
5. Xu, L., Wu, Y.H., Cheng, H., Sun, C., Han, B.N., Xu, X.W.: Complete genome sequence of Erythrobacter seohaensis SW-135T sheds light on the ecological role of the genus Erythrobacter for phosphorus cycle in the marine environment. Mar. Genomics. 34, 1-4 (2018).

6. Kadari, R., Merugu, R., Girisham, S., Reddy, S. M.: Impact of cultural conditions on photoproduction of hydrogen by Allochromatium sp. GSKRLMBKU-01 isolated from marine water of Visakhapatnam. Int. J. Hydrogen Energy. 43, 6060-6065. (2018).

7. Wang, X., Wang, Y., Cheng, X., Sun, D., Ren, Y., Xu, G.: Formation characteristics of an anoxygenic photosynthetic bacterial biofilm in a photorotating biological contactor for azo dye wastewater treatment. J. Chem. Technol. Biotechnol. 90, 176-184 (2015).

8. Hülsen, T., Barry, E. M., Lu, Y., Puyol, D., Keller, J., Batstone, D.J.: Domestic wastewater treatment with purple phototrophic bacteria using a novel continuous photo anaerobic membrane bioreactor. Water Res. 100, 486-495 (2016).

9. Khuong, N.Q., Kantachote, D., Onthong, J., Sukhoom, A.: The potential of acid-resistant purple nonsulfur bacteria isolated from acid sulfate soils for reducing toxicity of $\mathrm{Al}^{3+}$ and $\mathrm{Fe}^{2+}$ using biosorption for agricultural application. Biocatal. Agric. Biotechnol. 12, 329-340 (2017).

10. Su, Y.Q., Zhao, Y.J., Wu, N., Chen, Y.E., Zhang, W.J., Qiao, D.R., Cao, Y.: Chromium removal from solution by five photosynthetic bacteria isolates. Appl. Microbiol. Biotechnol. 102,1983-1995 (2018).

11. Idi, A., Md Nor, M.H., Abdul Wahab, M.F., Ibrahim, Z. Photosynthetic bacteria: An eco-friendly and cheap tool for bioremediation. Rev. Environ. Sci. Bio/Technology. 14: 271-285 (2015).

12. Millerick, K.A., Johnston, J.T., Finneran, K.T. Photobiological transformation of hexahydro-1,3,5trinitro-1,3,5-triazine (RDX) using Rhodobacter sphaeroides. Chemosphere. 159, 138-144. (2016). doi: 10.1016/j.chemosphere.2016.05.056

13. Meng, F., Yang, A., Zhang, G., Wang, H. Effects of dissolved oxygen concentration on photosynthetic bacteria wastewater treatment: Pollutants removal, cell growth and pigments production. Bioresour. Technol. 241, 993-997 (2017). doi: 10.1016/j.biortech.2017.05.183

14. Suresh, G., Sailaja, B., Ashif, A., Dave, B. P., Sasikala, C. Ramana, C.V.: Description of Rhodobacter azollae sp. nov. and Rhodobacter lacus sp. nov. Int. J. Syst. Evol. Microbiol. 67, 3289-3295 (2017).

15. Brenner, D.J., Krieg, N.R. Staley, J.R.: Bergey's Manual Systematic Bacteriology. pp. 300-350. Springer, New York (2005). 